\title{
The Efficiency of Water Management in the Area of Poland-Chosen Aspects
}

\author{
Zbigniew Piepiora \\ Wroclaw University of Environmental and Life Sciences, Wroclaw, Poland \\ Marian Kachniarz, Arkadiusz Babczuk \\ Wroclaw University of Economics, Wroclaw, Poland
}

\begin{abstract}
In 1997 and 2010, two great floods occurred in the area of Poland. In the year 2015, the area of Poland was affected by extreme temperature. In the time of global warming, the water management should play significant role. Thus, the purpose of the paper is to verify the efficiency of the water management in Poland. The methodology consists of two parts: data collection and data analysis. The data were collected from two databases: the EM-DAT (Emergency Events Database) and the BDL-GUS (Local Data Bank of the Central Statistical Office of Poland). After the analysis, conclusions were drawn. The hypothesis of the paper was verified negatively: The efficiency of the water management in Poland did not become better after the great flood in the year 2010. In the period 1998-2009, the average cost of building $1 \mathrm{~km}$ levees achieved 388,000 US\$ and in the years 2010-2014-606,000 US\$. The situation is similar in the case of regulation and development of rivers and streams. In the period 1998-2009, the average cost of regulating and developing rivers and streams $1 \mathrm{~km}$ levees was 155,000 US\$ and in the years 2010-2014-249,000 US\$.
\end{abstract}

Keywords: efficiency, Poland, natural disaster, financing, global warming

In 1997 and 2010, two great floods occurred in Poland. The most devastating inundation in the Oder River basin recently happened in 1997 and in the Vistula River basin - 2010. In 2015, the area of Poland was affected by extreme temperature. According to some sources, it was drought (WP Money.pl, 2015).

Floods, extreme temperatures, and droughts are examples of natural disasters (Abbott, 2009; Alexander, 1993). These phenomena can be defined, according to the Natural Disaster Act, as events connected with impacting of nature's forces (Ustawa, 2002). In the time of global warming, the water management should play significant role (Piepiora, 2012a).

Because the data concerning the drought in the year 2015 are still being estimated, the aim of this paper is to verify the hypothesis: The efficiency of the water management in Poland bettered after the great flood in the year 2010. The research question of the paper is: Whether the efficiency of the water management after 2010 is better than that before 2010 ?

Corresponding author: Zbigniew Piepiora, Ph.D., volunteer firefighter and tour guide for the area of Sudetes, Wroclaw University of Environmental and Life Sciences, Wroclaw, Poland; research fields: efficiency, finance, natural disasters, emergency management.

Marian Kachniarz, Ph.D., Prof., Wroclaw University of Economics, Wroclaw, Poland; research fields: local and regional economics, effectiveness of public administration.

Arkadiusz Babczuk, Ph.D., member of the Regional Chamber of Audit in Wroclaw, Wroclaw University of Economics, Wroclaw, Poland; research fields: public finance, public economy, public debt management. 
It is worth to notice that the paper is part of the research project "Financing catastrophic damages" chaired by PhD Zbigniew Piepiora (Piepiora, Babczuk, \& Kachniarz, 2015).

\section{The Methodology}

The methodology consists of two parts: data collection and data analysis. The data were collected from two databases: the EM-DAT (Emergency Events Database) and the BDL—GUS (Local Data Bank of the Central Statistical Office of Poland) (GUS, 2015).

The EM-DAT was established in 1988 by the Centre for Research on the Epidemiology of Disasters (CRED). It was created with the initial support of the WHO (World Health Organization) and the Belgian Government. The main goal of the EM-DAT database is to serve the purposes of humanitarian action at national and international levels. The EM-DAT contains essential core data on the occurrence and effects of over 18,000 mass disasters in the world from 1900 to present. The database is compiled from various sources, including UN agencies, non-governmental organisations, insurance companies, research institutes, and press agencies (Guha-Sapir, Below, \& Hoyois, 2016). The EM-DAT data (Advanced Search for natural disasters in Poland) concern the period 1919-2015 because Poland was recreated as the independent country on 11 November, 1918 after the World War I and 123 years of partitions by Austria-Hungary, Germany, and Russia (Dybkowska, J. Żaryn, \& M. Żaryn, 1994).

The BDL-GUS is the largest database in Poland and has ordered set of information about the social, socio-economic, demographic state of the environment, describing provinces, counties, and municipalities as agents of the system of social organization and administration of Poland. The BDL - GUS also describes regions and sub-regions constituting elements of the nomenclature of territorial units for statistical purposes (GUS, 2015). The BDL - GUS data concern the period 1998-2014 because only data for these years were available.

After collecting the data, the analysis in spreadsheet was conducted. The data was converted from CSV files and presented in tables and figures. In the case of BDL-GUS data, the currency were changed in the spreadsheet from Polish Zloty to US dollar using the exchange rate of the website MyBank.pl (MyBank.pl, 2015). After the analysis, conclusions were drawn.

\section{The Examined Area}

The Republic of Poland is located at the Baltic Sea in the Middle-East Europe. The south part of Poland has two mountain ranges called the Carpathian Mountains (Karpaty) and the Sudetes (Sudety). The main rivers of the country are Vistula (Wisła) and Oder (Odra). The climate of Poland is characterized as a transient of the mesothermal zone.

Table 1

The Manifestation of the Natural Disasters and Their Effects in the Area of Poland in Years 1919-2015

\begin{tabular}{llllllll}
\hline Disaster type & Occurrence & Total deaths & Affected & Injured & Homeless & Total affected & Total damage \\
\hline Earthquake & 1 & 0 & 1,050 & 0 & 0 & 1,050 & 0 \\
Extreme temperature & 16 & 1,841 & 0 & 0 & 0 & 0 & 0 \\
Flood & 13 & 113 & 304,750 & 0 & 63,824 & 368,574 & $7,933,000$ \\
Storm & 15 & 129 & 2,250 & 155 & 0 & 2,405 & 219,050 \\
Wildfire & 2 & 35 & 0 & 0 & 0 & 0 & 0 \\
\hline
\end{tabular}

Note. Source: D. Guha-Sapir, 2016. 
The manifestation of the natural disasters and their effects in the area of Poland in the period 1919-2015 is presented in Table 1. As we can see at the figures, extreme temperatures and floods occurred most often in the examined area. Deaths were caused mostly by extreme temperatures. People were mostly affected by floods. Total damage was also caused by foods that are hydrometeorological disasters (Rodzik, 2008; Somorowska, 2009).

\section{The Efficiency of the Water Management in the Examined Area}

Counteracting effects of extreme temperatures, droughts, and floods in Poland are executed mainly on the basis of the Water Law Act (Ustawa, 2001). According to the first mentioned act, the National Water Management Authority (KZGW) is responsible for preventing the negative consequences of the global warming. It is directed by the president, and is subjected to the Minister of the Environment. The KZGW has seven regional divisions (Piepiora, 2012b).

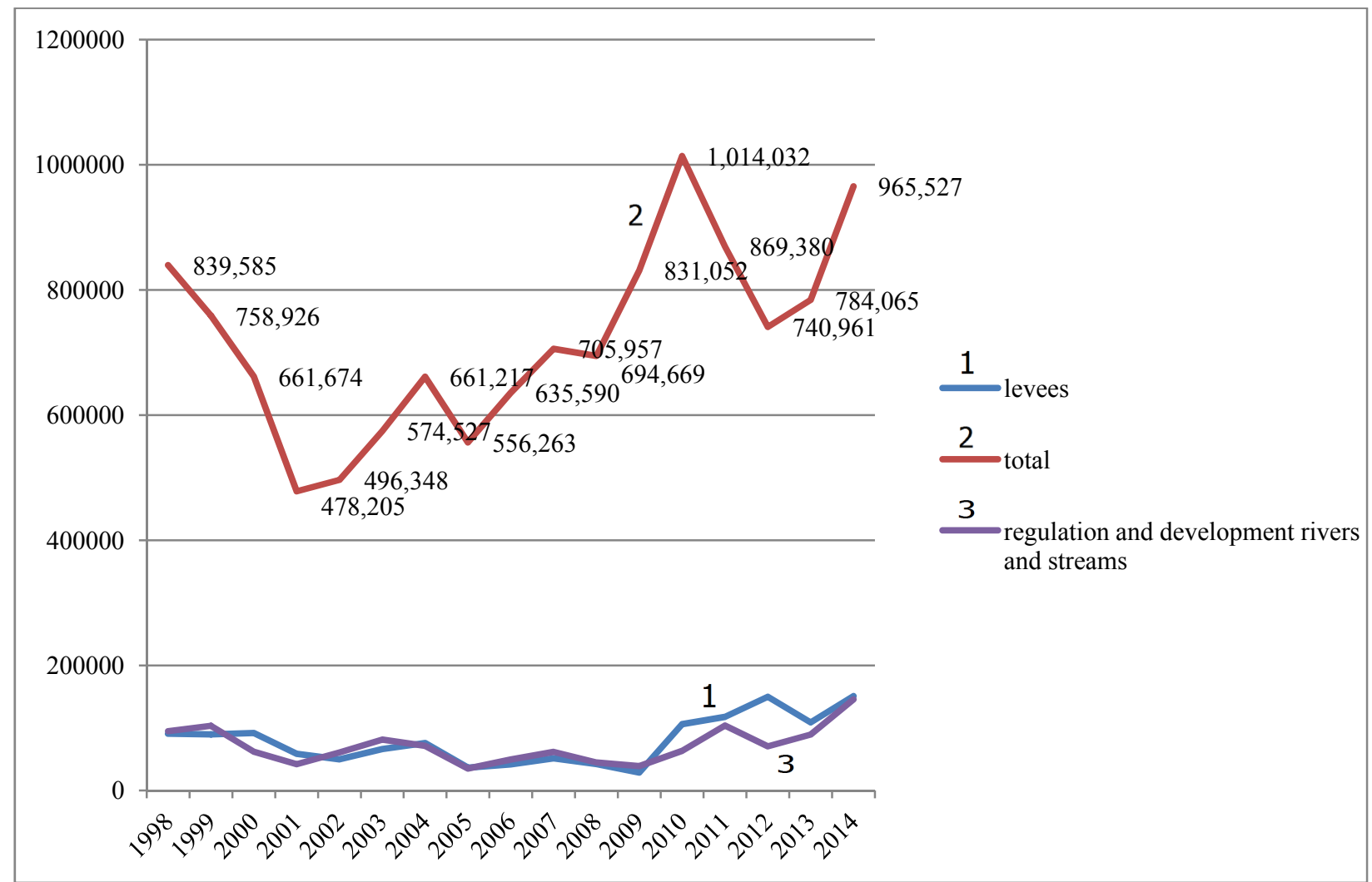

Figure 1. Expenditures for permanent assets serving the water management in Poland in the period 1998-2014 - directions of investing (in '000 US dollar indexed to the year 2014). Source: Own study on the basis of: GUS (2015); MyBank.pl (2015); and Piepiora, Kachniarz, and Babczuk (2015).

Expenses for permanent assets serving the water management in Poland in the period 1998-2014 according to directions of investing are presented in Figure 1. Total expenses for permanent assets serving the water management in the examined period in Poland amounted approximately 12.3 billion US dollars indexed to the year 2014. Total expenses and expenditures for regulation and development of rivers and streams were decreasing after the great flood in 1997. After the great flood in 2010, it was observed the highest level of total expenses and expenditures for levees, and water reservoirs and stages. 


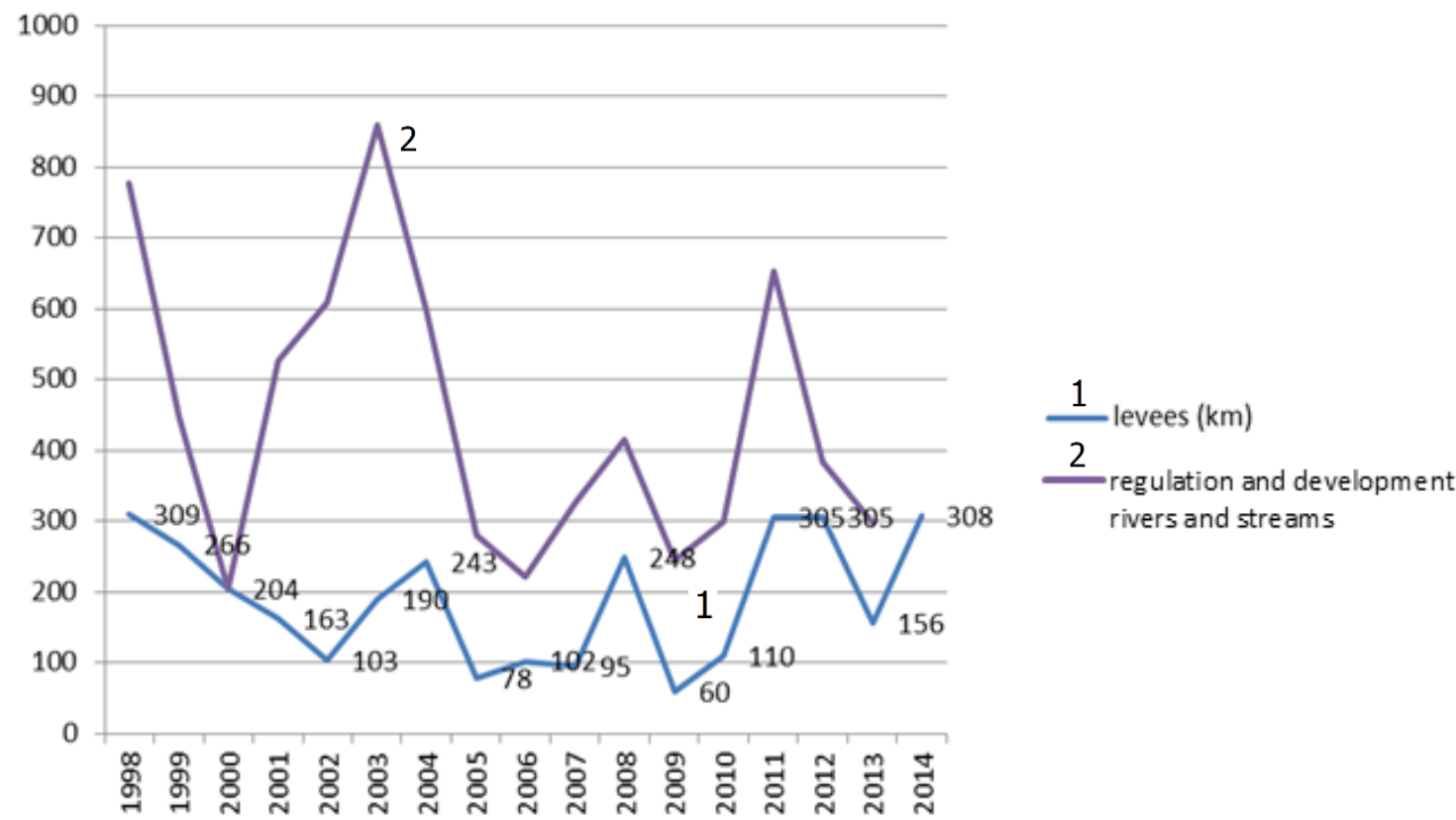

Figure 2. Effects of investing in the water management in Poland in the period 1998-2014. Source: Own study on the basis of: GUS, 2015; MyBank.pl, 2015; Piepiora, Babczuk, \& Kachniarz, 2016.

Effects of investing in the water management in the period 1998-2014 in Poland are presented in Figure 2. As we can see, data of table are corresponding with data of Figure 1. In the years 1998-2014, there were 6,039 $\mathrm{km}$ rivers and streams regulated and developed and 2,467 km levees built. After the great flood in 2010, almost $37 \%$ length of levees were built.

Table 2

Expenditures, Effects, and Efficiency of Permanent Assets Serving the Water Management in Poland in the Period 1998-2014 (in '000 US Dollar Indexed to the Year 2014)

\begin{tabular}{llllllll}
\hline & \multicolumn{3}{c}{ Expenditures } & \multicolumn{2}{c}{ Effects } & \multicolumn{2}{c}{ Efficiency } \\
\hline Years & Total & 1 & 2 & 1 & 2 & 1 & 2 \\
\hline 1998 & 839,585 & 90,829 & 94,881 & 309 & 777 & 294 & 122 \\
1999 & 758,926 & 89,713 & 103,438 & 266 & 447 & 337 & 232 \\
2000 & 661,674 & 91,952 & 62,001 & 204 & 205 & 450 & 302 \\
2001 & 478,205 & 58,776 & 42,151 & 163 & 527 & 360 & 80 \\
2002 & 496,348 & 49,859 & 60,969 & 103 & 609 & 484 & 100 \\
2003 & 574,527 & 66,217 & 81,542 & 190 & 859 & 348 & 95 \\
2004 & 661,217 & 75,779 & 71,532 & 243 & 597 & 312 & 120 \\
2005 & 556,263 & 36,391 & 35,178 & 78 & 280 & 467 & 126 \\
2006 & 635,590 & 41,903 & 49,495 & 102 & 222 & 409 & 223 \\
2007 & 705,957 & 51,457 & 61,640 & 95 & 326 & 541 & 189 \\
2008 & 694,669 & 42,248 & 44,764 & 248 & 416 & 170 & 108 \\
2009 & 831,052 & 28,668 & 39,084 & 60 & 246 & 479 & 159 \\
2010 & $1,014,032$ & 106,170 & 63,492 & 110 & 299 & 968 & 212 \\
2011 & 869,380 & 117,686 & 103,924 & 305 & 654 & 386 & 159 \\
2012 & 740,961 & 149,983 & 70,640 & 305 & 385 & 491 & 184 \\
2013 & 784,065 & 108,878 & 89,510 & 156 & 297 & 697 & 301 \\
2014 & 965,527 & 150,890 & 145,796 & 308 & 374 & 490 & 390 \\
\hline
\end{tabular}


Table 2 to be continued

\begin{tabular}{llllllll}
\hline Total 1998-2009 & $7,894,014$ & 723,791 & 746,675 & 2,062 & 5,510 & 4,652 & 1,855 \\
Total 2010-2014 & $4,373,966$ & 633,607 & 473,363 & 1,184 & 2,009 & 3,032 & 1,246 \\
Total all years & $12,267,979$ & $1,357,398$ & $1,220,038$ & 3,246 & 7,518 & N/A & N/A \\
Average 1998-2009 & 657,834 & 60,316 & 62,223 & 172 & 459 & 388 & 155 \\
Average 2010-2015 & 874,793 & 12,6721 & 94,673 & 237 & 402 & 606 & 249 \\
Average & 721,646 & 79,847 & 71,767 & 191 & 442 & 452 & 182 \\
\hline
\end{tabular}

Notes. 1. Levees, 2. Regulation and development of rivers and streams. Source: Own study on the basis of: GUS, 2015; MyBank.pl, 2015.

Expenditures, effects, and efficiency of permanent assets serving the water management in Poland in the period 1998-2014 are presented in Table 2. In the years 1998-2009, the average cost of building $1 \mathrm{~km}$ levees totalled 388,000 US\$ and in the period 2010-2014-606,000 US\$. The similar situation is noted in the case of development and regulation of streams and rivers. The average cost of developing and regulating streams and rivers $1 \mathrm{~km}$ levees in the years 1998-2009 was 155,000 US\$ and in the period 2010-2014-249,000 US\$.

\section{Conclusions}

After the analysis of the efficiency of the water management in the area of Poland, the following conclusions can be drawn.

The hypothesis from the beginning of the paper was verified negatively: The efficiency of the water management in Poland did not become better after the great flood in the year 2010. Thus, the answer for the research question of the paper is: The efficiency of the water management after 2010 is not better than that before 2010 .

The average cost of building $1 \mathrm{~km}$ levees in the period 1998-2009 amounted to 388,000 US\$ and in the period 2010-2014 -606,000 US\$. In the case of regulation and development of rivers and streams, the situation is similar. The average cost of regulating and developing rivers and streams $1 \mathrm{~km}$ levees in the period 1998-2009 amounted to 155,000 US\$ and in the period 2010-2014-249,000 US\$.

It is worth to notice that this paper was limited by the time period of the research. The future research, headed by PhD Zbigniew Piepiora, will focus on extending of analysed time period and explaining why the efficiency of the water management in Poland did not become better after the great flood in the year 2010.

\section{References}

Abbott, P. L. (2009). Natural disasters. San Diego: San Diego State University.

Alexander, D. (1993). Natural disasters. Berlin: Wydawnictwo Springer Science \& Business.

Dybkowska, A., Żaryn, J., \& Żaryn, M. (1994). Polskie Dzieje. Od czasów najdawniejszych do współczesności (Polish history. From ancient times to the present day). Warszawa: PWN. P. 224.

Guha-Sapir, D., Below, R., \& Hoyois, P. (2016). EM-DAT: International disaster database. Université Catholiquede Louvain, Brussels, Belgium. Retrieved from http://www.emdat.be

GUS. (2015). Bank Danych Lokalnych (Local data bank). Retrieved from http://www.stat.gov.pl/bdl/app/strona.html?p_name =indeks

MyBank.pl. (2015). Kursywalut (Exchange rates). Retrieved from http://kursy-walut-kupno-sprzedaz.mybank.pl/

Piepiora, Z., Kachniarz, M., \& Babczuk, A. (2015). Preventing effects of natural disasters in Poland-Financial aspects. International Journal on Recent and Innovation Trends in Computing and Communication, 3(10), 5967-5971. Retrieved from http://www.ijritcc.org/browse/volume-3-issues/october-15-volume-3-issue-10/47

Piepiora, Z. (2012a). Ekonomiczne aspekty lokalnej polityki przeciwdziałania skutkom katastrof naturalnych (Economic aspects of natural disasters policy at the local level). wyd. Zbigniew Piepiora, Kowary. 
Piepiora, Z. (2012b). The law and economic aspects of counteracting the natural disasters' effects in the area of Poland. In H. X. Корецкий (Еd.), Сорременный НаучныйВестник (News of science and education) (pp. 104-119). Wydawnictwo Руснаучкнига, Коллективавторов, Белгород 2012 (Rus-science book, team of authors, Belgorod 2012).

Piepiora, Z., Babczuk, A., \& Kachniarz, M. (2015). Financing the counteraction of natural disasters' effects in lower Silesian Voivodeship. Retrieved from http://www.atlantis-press.com/php/pub.php?publication=icmemi-15\&frame=http $\% 3 \mathrm{~A} / / \mathrm{www}$. atlantis-press.com/php/paper-details.php\%3Ffrom\%3Dsession+results\%26id\%3D16211\%26querystr\%3Did\%253D304

Piepiora, Z., Babczuk, A., \& Kachniarz, M. (2016). Active natural disasters policy in Poland. Proceedings from the 2016 International Conference on Intelligent Control and Computer Application in Advances in Computer Science Research. Paris-Amsterdan-Beijing: Atlantis Press. Pp. 194-197. Retrieved from http://www.atlantis-press.com/php/pub.php?publicat ion=icca- 16

Rodzik, J. (2008). Wpływ deszczów ulewnych i roztopów na rozwój wąwozu lessowego (The impact of torrential rains and thaws on the development of the loess ravine). In Landform analysis. Vol. 8. Poznań: Stowarzyszenie Geomorfologów Polskich.

Somorowska, U. (2009). Wzrost zagrożenia suszą hydrologiczną w różnych regionach geograficznych Polski w XX wieku (The increase in risk of hydrological drought in different geographical regions of Poland in the twentieth century). In Prace $i$ Studia Geograficzne (Papers and geographical studies) (pp. 97-114). Tom 43. Warszawa: Uniwersytet Warszawski.

Ustawa. (2001). z dnia 18 lipca 2001 roku Prawo wodne, Dz. U. 2001 nr 115 poz. 1229 z późniejszymi zmianami (The Water Law of 18 July 2001 Journal Laws of 2001 No. 115, item 1229, as amended).

Ustawa. (2002). z dnia 18 kwietnia 2002 r. o stanie klęski żywiołowej Dz. U. 2002 nr 62 poz. 558 z późniejszymi zmianami (The Natural DisasterAct of 18 April 2002 Journal Laws of 2002 No. 62, item 558, as amended).

WP Money.pl. (2015). Susza w Polsce. Straty rolników sq już szacowane na 1 mld zl, zagrożone 99 proc. upraw (Drought in Poland. The losses of farmers are now estimated at 1 billion $z$, threatened 99 percent crops). Retrieved from http://www.money.pl/ gospodarka/wiadomosci/artykul/susza-w-polsce-straty-rolnikow-sa-juz, 158,0,1899422.html 